\title{
Isolation and Characterization of Polymorphic Microsatellite Loci in the Redclaw Crayfish, Cherax Quadricarinatus
}

Lin $\mathrm{He}^{1}$, Jing $\mathrm{Xie}^{1}$, Qing $\mathrm{Li}^{1}$, Yunlong Zhao', Yaping Wang ${ }^{2}$ and Qun Wang ${ }^{1 *}$

${ }^{1}$ School of Life Science, East China Normal University, Shanghai 200062, China

${ }^{2}$ Institute of Hydrobiology, Chinese Academy of Sciences, Wuhan 430072, China

\begin{abstract}
Here we developed and optimized 15 polymorphic microsatellites isolated from Cherax quadricarinatus enriched for CA repeats. We tested variability of these microsatellites in 60 unrelated individuals cultured in China. All microsatellite loci were polymorphic. Number of alleles per locus ranged from 2-7 while observed and expected heterozygosities ranged from 0.2549 to 0.8615 and from 0.3405 to 0.8174 , respectively. Fourteen of the 15 microsatellites conformed to Hardy-Weinberg Equilibrium. These microsatellite loci developed here provide an important resource for studying genetic diversity and population structure in redclaw crayfish and potentially in other related species.
\end{abstract}

Keywords: Aquaculture; Microsatellites; Red claw crayfish; Polymorphism

\section{Introduction}

The redclaw crayfish Cherax quadricarinatus accounts for the entire commercial production of freshwater crayfish in Australia [1]. Its culture potential has also been recognized in other countries, including the USA and China, and this species was introduced to China in the early 1990s for commercial culture. Genetic markers can characterize relative levels of population variation and differentiation in both wild and cultured stocks [2]. Knowledge of populations is limited for cultured stocks in China and it is unlikely that much of the natural variation that exists across the large natural range of this species has been exploited in culture. So our work on SSR markers isolation and studies of genetic diversity and population structure will provide important information for promoting development of aquaculture of C. quadricarinatus in China.

Microsatellites are simple DNA sequences, repeated in tandems that are widely dispersed across the genomes of eukaryotic and prokaryotic organisms. Most loci are highly variable and considered to be selectively neutral, making them amenable to population genetic analysis [3]. Until now, only a limited number of microsatellite loci have been developed for C. quadricarinatus [4]. Thus, isolation of more microsatellite loci from C. quadricarinatus will be important for elucidating population structure and for monitoring relative levels of genetic diversity in sampled populations.

\section{Materials and Methods}

\section{Sampling and DNA isolation}

The cultured C. quadricarinatus individual samples were collected from Xia Men in China. Total genomic DNA was extracted from muscle tissues using the standard proteinase $\mathrm{K}$-phenol-chloroform method [5].

\section{The isolation of microsatellite loci}

Microsatellites were isolated using a magnetic beads enrichment procedure with modifications [6]. Two genomic DNA samples from male and female individuals were first pooled. About $10 \mu \mathrm{g}$ of DNA was then digested with Mse I and purified with Wizard PCR Purification kit (Promega and ligated to the adaptors (ADP1: 5'-AGATGGAATTCGTACACTCGT-3' and antisense strand ADP2:
5'-TAACGAGTGTACGAATTCCATCT-3'). Magnetic beads captured DNA containing microsatellites were eluted in $30 \mu \mathrm{L}$ water. DNA enriched with microsatellites was amplified in a $25 \mu \mathrm{L}$ reaction using the ADP1 as primer to know the successful ligation [7]. PCR products of $25 \mu \mathrm{L}$ were electrophoresed on $1 \%$ agarose gel, fragments between 400 $1000 \mathrm{bp}$ were cut from the gel and purified by Wizard PCR Purification kit (Promega). About 50ng concentrated DNA was directly ligated to 25 ng pGEM-T vector (Promega) according to the manufacturer's protocol. The ligation products were transformed into Escherichia coli TOP 10 competent cells (Tiangen) and plated upon LB-agar containing $50 \mathrm{mg} / \mathrm{L}$ ampicilin, $60 \mathrm{mg} / \mathrm{L} \mathrm{IPTG}$, and $40 \mathrm{mg} / \mathrm{L}$ X-gal. A partial genomic DNA library enriched for CA- microsatellites was established. White clonies were picked into 96-well Deep Well Plates and cultured at $37^{\circ}$ with shaking for $4 \mathrm{~h}$. A PCR-based method was used to screen recombinant clones using M13 and (CA) as primers. We only select the clones that have two or more amplified bands in the PCR products, which ensure these clones contain CA or GT repeats fragment [8]. 45 selected clones with repeat elements were sequenced with M13 universal primer (Invitrogen), of which 30 unique sequences were chosen for primer design using PRIMER PREMIER 5.0 (PREMIER Biosoft International).

\section{Detection of polymorphic microsatellite loci}

To characterize the isolated microsatellites, we obtained 60 cultured redclaw crayfish individuals from Xia Men in Fu Jian province. Total genomic DNA was then extracted from these individuals as templates. PCR were performed in $25 \mu \mathrm{L}$ reactions each containing: $20 \mathrm{ng}$ DNA, $0.5 \mathrm{U}$ Taq Polymerase (TaKaRa), $1 \times$ PCR reaction buffer $\left(\mathrm{Mg}^{2+}, 0.2 \mathrm{mM}\right.$ of each primer, $0.2 \mathrm{mM}$ of each $\mathrm{dNTP}$ and $\mathrm{ddH}_{2} \mathrm{O}$ in a final volume of $25 \mu \mathrm{L}$. PCR conditions were as follows: $94^{\circ} \mathrm{C}$ for $3 \mathrm{~min}$ followed by

*Corresponding author: Qun Wang, School of Life Science, East China Normal University, Shanghai 200062, China, Tel. +86 21 24206614; E-mail: hallie@126.com

Received September 20, 2012; Accepted November 23, 2012; Published November 30, 2012

Citation: He L, Xie J, Li Q, Zhao Y, Wang Y, et al. (2013) Isolation and Characterization of Polymorphic Microsatellite Loci in the Redclaw Crayfish Cherax Quadricarinatus. J Aquac Res Development 4:162 doi:10.4172/21559546.1000162

Copyright: (c) $2013 \mathrm{He} \mathrm{L}$, et al. This is an open-access article distributed under the terms of the Creative Commons Attribution License, which permits unrestricted use, distribution, and reproduction in any medium, provided the original author and source are credited. 
Citation: He L, Xie J, Li Q, Zhao Y, Wang Y, et al. (2013) Isolation and Characterization of Polymorphic Microsatellite Loci in the Redclaw Crayfish, Cherax Quadricarinatus. J Aquac Res Development 4:162 doi:10.4172/2155-9546.1000162

Page 2 of 3

\begin{tabular}{|c|c|c|c|c|c|c|c|c|c|c|}
\hline Locus name & Repeat motif & Primer pair sequence $\left(5^{\prime}-3^{\prime}\right)$ & $\begin{array}{l}T m \\
\left({ }^{\circ} \mathrm{C}\right)\end{array}$ & Size range & $\begin{array}{l}\text { No of } \\
\text { alleles }\end{array}$ & HO & $H E$ & $\begin{array}{l}\text { HEW } \\
P \text {-value }\end{array}$ & $P I C$ & $\begin{array}{l}\text { GenBank } \\
\text { Accession no. }\end{array}$ \\
\hline CQ1 & (GT)16 & $\begin{array}{l}\text { F:ACCTGTCGCACTCTGTATCAA } \\
\text { R:ACCTAGTAGCGATCAATGAAGAG }\end{array}$ & 56.4 & $273-293$ & 3 & 0.6897 & 0.6439 & 0.6878 & 0.5617 & HM035026 \\
\hline CQ2 & (CA)42 & $\begin{array}{l}\text { F:TCACCAGGCTTTGAAATAGT } \\
\text { R:CATTTGCCGTCTTCCATACC }\end{array}$ & 56.4 & $180-240$ & 7 & 0.8167 & 0.8174 & 0.2154 & 0.7850 & HM035027 \\
\hline CQ3 & (GT)24 & $\begin{array}{l}\text { F:ACTTCTCTGTGTATATATCCTGTG } \\
\text { R:CAGACACCAAACACCAAGAT }\end{array}$ & 56.4 & 154-193 & 3 & 0.3103 & 0.3405 & 0.1834 & 0.3121 & HM035028 \\
\hline CQ4 & (TG)13 & $\begin{array}{l}\text { F:TAGCACCAGAGAGAGTCAGG } \\
\text { R:TGGAGCAGGAAAAGTGAG }\end{array}$ & 56.4 & $183-200$ & 3 & 0.5000 & 0.5118 & 0.4754 & 0.3868 & HM035029 \\
\hline CQ5 & (AC) 15 & $\begin{array}{l}\text { F:TAGTAGCGACCAGTGAAGAG } \\
\text { R:GCGTTGTTTTGACACAGAAG }\end{array}$ & 56.4 & $187-237$ & 4 & 0.5714 & 0.6173 & 0.0817 & 0.5322 & HM035030 \\
\hline CQ6 & (CA) 23 & $\begin{array}{l}\text { F:CTAGTCGCTACCAGCAAAGA } \\
\text { R:CAACCTCCTGGGACTTACTG }\end{array}$ & 50.4 & $408-418$ & 2 & 0.6032 & 0.4246 & 1.0000 & 0.3325 & HM035031 \\
\hline CQ7 & (TG)22 & $\begin{array}{l}\text { F:TGTCTTCAACTTCCAACTGTG } \\
\text { R:ATAAATGTGAGAGCCCAGGT }\end{array}$ & 50.4 & $175-246$ & 3 & 0.7600 & 0.6305 & 0.9729 & 0.5478 & HM035032 \\
\hline CQ8 & (TG)14 & $\begin{array}{l}\text { F:TCCCTGTGATTCATCTGTTT } \\
\text { R:GTAGCGATCAGTGAAGAGGC }\end{array}$ & 63.9 & $382-405$ & 2 & 0.8000 & 0.4837 & 1.0000 & 0.3648 & HM035033 \\
\hline CQ9 & (TG)13 & $\begin{array}{l}\text { F:CTCCACTATTCTGTTTGCTTTG } \\
\text { R:GTAGCAATAAGCGAAGAGGC }\end{array}$ & 62.7 & 171-175 & 2 & 0.4688 & 0.3780 & 0.9944 & 0.3047 & HM035034 \\
\hline CQ10 & (CA)18 & $\begin{array}{l}\text { F:ACACACACGCACAAGGGTAGAC } \\
\text { R:CCGATTTCCCTCAACCTTTC }\end{array}$ & 62.7 & $261-289$ & 4 & 0.8615 & 0.6730 & 0.9998 & 0.6101 & HM035035 \\
\hline CQ11 & (TG)11 & $\begin{array}{l}\text { F:CCATTGTACCTCCCTTTTTT } \\
\text { R:CAGCCACAGTAGCAGTCAGT }\end{array}$ & 50.4 & 332-365 & 2 & 0.2549 & 0.3931 & $0.0171^{*}$ & 0.3135 & HM035036 \\
\hline CQ12 & (AC) 40 & $\begin{array}{l}\text { F:GTTCAGGGAGAGTGACCTAGTAGC } \\
\text { R:CCTCCTCGGTTGTTATGTTATT }\end{array}$ & 50.4 & 389-403 & 2 & 0.6000 & 0.4923 & 0.9533 & 0.3675 & HM035037 \\
\hline CQ13 & (GT)37 & $\begin{array}{l}\text { F:TGTGACCCCTTGTTTCTGTG } \\
\text { R:GCCCGTCATTCAAGCCAAAG }\end{array}$ & 63.9 & $239-258$ & 3 & 0.3810 & 0.5116 & 0.0978 & 0.4551 & HM035038 \\
\hline CQ14 & (TG)29 & $\begin{array}{l}\text { F:TTTCCTCAGCCTTATCACCT } \\
\text { R:GGTAATGAACTCTGGGTAGGTC }\end{array}$ & 55.0 & $330-363$ & 3 & 0.8537 & 0.5285 & 1.0000 & 0.4188 & HM035039 \\
\hline CQ15 & (TG)26 & $\begin{array}{l}\text { F:ATACTCCCTCTTGGTGTTCC } \\
\text { R:GTAGCGGTCAGTGAAGAGGC }\end{array}$ & 63.9 & $380-403$ & 2 & 0.7846 & 0.4805 & 1.0000 & 0.3631 & HM035040 \\
\hline Average & & & & & 3 & 0.6171 & 0.5284 & 0.6453 & 0.4437 & \\
\hline
\end{tabular}

$\mathrm{H}_{\mathrm{O}}$, observed heterozygosity; HE, expected heterozygosity; HWE, Hardy-Weinberg equilibrium; PIC, polymorphic information content of each locus; and GenBank accession numbers for DNA sequences of loci; * Locus deviating from HWE.

Table 1: Microsatellite isolated from Redclaw Crayfish (Cherax quadricarinatus).

35 cycles of $94^{\circ} \mathrm{C}$ for $30 \mathrm{~s}$, annealing temperature for $30 \mathrm{~s}$ and $72^{\circ} \mathrm{C}$ for $30 \mathrm{~s}$ with a final extension for $10 \mathrm{~min}$ at $72^{\circ} \mathrm{C}$. Amplified products were separated on QIAxcel DNA High Resolution Cartridge (QIAGEN, Shenzhen, China) using the QIAxcel System (QIAGEN, Germany) and the resulting data were analysed with BioCalculator software [9]. The QIAxcel provides an automated system that increases sample throughput, reducing labour costs and decreasing sample processing time [10].

\section{Results and Discussion}

We screened 72 recombinant clones with M13 and (CA) primers, 45 selected clones with repeat elements were sequenced with M13 universal primers (Invitrogen). We designed and tested a total of 30 primer pairs, 12 of them failed to amplify or showed complex amplification, three were monomorphic and 15 were polymorphic in the population screened here. The number of alleles, observed and expected heterozygosities were analyzed by Popgen32 [11]. The number of alleles per polymorphic loci varied from 2 to 7 and the values of observed heterozygosity and expected heterozygosity ranged from 0.2549 to 0.8615 and from 0.3405 to 0.8174 , respectively (showed in table 1).

$\mathrm{P}$ value for Hardy-Weinberg equilibrium (HWE) estimates and linkage disequilibria were estimated by using Genepop [12]. Except locus CQ11, fourteen loci conformed to Hardy-Weinberg Equilibrium in the population $(\mathrm{P}>0.05)$. Observed deviations from HWE expectations may result from sampling effects, presence of null alleles or excessive heterozygosity. Linkage disequilibria (LD) was detected between CQ3 × CQ14, CQ3 × CQ10, CQ3 × CQ9, CQ7× CQ9, CQ7 $\times$ CQ13, CQ8 $\times$ CQ15 $(P<0.05)$ and indicate that these loci may be physically linked on individual chromosomes in redclaw. We suggest that potential linked loci identified here should be used with caution, and perhaps only one from each set should be used in order to avoid pseudo-replication in population genetic analyses.

Polymorphism information content (PIC) is recognized as a measure of the relative utility of molecular markers [13] and comparisons of PIC values can provide an estimate of the relative power of individual markers [14]. Per-locus PIC values here ranged from 0.3047 (CQ9) to 0.7850 (CQ2) respectively, with a mean of 0.4437. Five of the 13 polymorphic loci identified were shown to be highly informative (PIC $>0.5)$. The remaining ten loci were moderately informative $(0.25<\mathrm{PIC}<0.5)$, and none was only slightly informative (PIC $<0.25)$. This indicates that the set of microsatellites developed here show considerable potential for analyzing genetic polymorphisms in red claw populations.

All the results are shown in table 1. Until recently, there are only a few DNA markers available for the red claw crayfish. Therefore, these 15 novel microsatellite markers could facilitate studies on genetic diversity 
Citation: He L, Xie J, Li Q, Zhao Y, Wang Y, et al. (2013) Isolation and Characterization of Polymorphic Microsatellite Loci in the Redclaw Crayfish, Cherax Quadricarinatus. J Aquac Res Development 4:162 doi:10.4172/2155-9546.1000162

and population structure of the red claw crayfish to supply useful information for conservation of cultured stocks, and even potentially used in the study of other related freshwater crayfish species.

\section{Acknowledgements}

This study was supported by grants from Science and Technology Commission of Shanghai Municipality (08JC1408300 and 08DZ1906401) and collaborated with the State Key Laboratory of Freshwater Ecology and Biotechnology (2010FB13) in Institute of Hydrobiology, Chinese Academy of Sciences, Wuhan. We would like to thank Shuai Zhan and PanYu Hua for their help with software.

\section{References}

1. Julie M Macaranas, Peter B Mather, Peter Hoeben, Michael E Capra (1995) Assessment of Genetic Variation in Wild Populations of the Redclaw Crayfish (Cherax quadricarinatus, von Martens 1868) by Means of Allozyme and RAPDPCR Markers. Mar Freshwater Res 46: 1217-1228.

2. Baker N, Bruyn MD, Mather P (2008) Patterns of molecular diversity in wild stocks of the redclaw crayfish (Cherax quadricarinatus) from northern Australia and Papua New Guinea: impacts of Plio-Pleistocene landscape evolution. Freshwater Biology 53: 1592-1605.

3. Liu YL, Liu LX, Wu ZX, Lin H, Li BF, et al. (2006) Isolation and characterization of polymorphic microsatellite loci in black sea bream (Acanthopagrus schlegeli) by cross-species amplification with six species of the Sparidae family. Aquat Living Resour 20: 257-262.

4. Baker N, Byrne K, Moore S, Mather P (2000) Characterization of microsatellite loci in the redclaw crayfish, Cherax quadricarinatus. Mol Ecol 9: 494-495.

5. Sambrook JD, Russell W (2000) Molecular cloning: alaboratory manual, 2nd edn. Cold Spring Harbor Laboratory Press, NewYork.
6. Fischer D, Bachmann K (1998) Microsatellite enrichment in organisms with large genomes (Allium cepa L.). Biotechniques 24: 796-800.

7. Brown J, Hardwick LJ, Wright AF (1995) A simple method for rapid isolation of microsatellite from yeast artificial chromosomes. Mol Cell Probes 9: 53-57.

8. Vignes H, Hossaert MM, Beaune D, Fevre D, Anstett MC, et al. (2006) Development and characterization of microsatellite markers for a monoecious Ficus species, Ficus insipida, and cross-species amplification among different sections of Ficus. Molecular Ecology Notes 6: 792-795.

9. Claire L Mc Murray, Katherine J Hardy, Peter M Hawkey (2010) Rapid automated epidemiological typing of methicillin-resistant Staphylococcus aureus. J Microbiol Methods 80: 109-111.

10. Xinwang Wang, Timothy A Rinehart, Phillip A Wadl, James M Spiers, Denita Hadziabdic, et al. (2009) A new electrophoresis technique to separate microsatellite alleles. African Journal of Biotechnology 8: 2432-2436.

11. Rousset F, Raymond M (1995) Testing heterozygote excess and deficiency. Genetics 140: 1413-1419.

12. Raymond M, Rousset F (2004) GENEPOP (version3.4): population genetics software for exact tests and ecumenicism. Available at: http://wbiomed.curtin edu.au/genepop/.html

13. Botstein D, White RL, Skolnick M, Davis RW (1980) Construction of a genetic linkage map in man using restriction fragment length polymorphisms. Am J Hum Genet 32: 314-331.

14. Liu ZJ, Cordes JF (2004) DNA marker technologies and their applications in aquaculture genetics. Aquaculture 238: 1-37. 